\title{
Diabetes mellitus in the australian indigenous community
}

Lelia L. F. de Abreu, Ken Walder and Yann Gibert*

*Correspondence: y.gibert@deakin.edu.au

Metabolic Genetic Diseases Laboratory, Metabolic Research Unit, School of Medicine, Deakin University, Waurn Ponds, Victoria, Australia.

\begin{abstract}
This report aims to investigate the higher prevalence of type 2 diabetes (T2D) among Indigenous Australians, with recommendations to Australians Health Professionals in order to increase awareness of Indigenous health peculiarities related to diabetes mellitus (DM). Diabetes has become one of the most common public health problems of the $21^{\text {st }}$ century. The proportion of Aborigines Australians developing T2D is 5 to 10 times greater than non-Aborigines. Although DM in Aboriginal community is multifactorial, this report shows three perceived causes: (i) obesity and the "Thrifty Gene Hypothesis", (ii) geographical position and (iii) smoking. It concluded that the combination of these causes have increased the incidence of DM among Indigenous Australians. Therefore, the following are recommended: improvement of genetic research, improvement of medical facilities, and increased employment of Indigenous Health Professionals and improvement of anti-smoking policies.
\end{abstract}

Keywords: Diabetes mellitus, aborigine, Australia, obesity

\section{Introduction}

Diabetes mellitus (DM) has become one of the most common public health problems of the $21^{\text {st }}$ century. It is a chronic metabolic disease characterized by high blood glucose levels (fasting glucose $\geq 7.0 \mathrm{mmol} / \mathrm{L}$ (or $126 \mathrm{mg} / \mathrm{dL}$ ) or plasma glucose $\geq 11.1 \mathrm{mmol} / \mathrm{L}$ (or $200 \mathrm{mg} / \mathrm{dL}$ ) after 2 hours ingestion of $75 \mathrm{~g}$ glucose) due to impaired insulin production and/or insulin resistance [1]. Importantly, the prevalence of DM among Aborigines Australians is 5 to 10 times greater than NonAborigines. As consequence of this, Indigenous Australians are 4 times more hospitalized than the rest of the Australian population [2]. Furthermore, the highest expenditure in PPH (Potentially Preventable Hospitalizations) is due to DM complications, and it is 4 times greater with Indigenous compared to Non-Indigenous Australians [3]. In addition, DM is also contributing to mortality among Aborigines, accounting for approximately $10 \%$ of all deaths [4]. The high prevalence of T2D is not exclusive for Australians Aborigines. It has been also reported in Pima Indians [5], Nauruans [6], and Mexican Americans [7]. One of the most prominent theories to explain the Aboriginal Australian susceptibility to DM is obesity and the "Thrifty Gene Hypothesis", which will be discussed in this review. Furthermore, several risk factors that can trigger DM related to the shift from the hunter-gatherer lifestyle to a more westernized lifestyle [8]. Therefore, the aim of this report is to investigate the causes of the higher rates of type 2 diabetes (T2D) in Indigenous Australians. The purpose of this article is to provide information to Australian Health Professionals in order to improve awareness of Indigenous health peculiarities related to $\mathrm{DM}$.

\section{Methods}

This review examines studies from MEDLINE (PubMed version) online database from 1980 to 2013, departing from the keywords: Australian Aborigine, Diabetes Mellitus type 2, Urbanization, Geographic, Smoking and Obesity. Australian Government and Diabetes Organizations research data were also included.

\section{Finding and discussion}

T2D is a multifactorial disease; (Figure 1) demonstrates a multifactorial model outlining the pathways to T2D in an Indigenous population [9]. Although DM in Aboriginal community is multifactorial, this report will focus on three perceived causes: obesity and the "Thrifty Gene Hypothesis", geographical position and smoking.

\section{Obesity and the "Thrifty Gene Hypothesis"}

The World Health Organization (WHO) defines overweight and obesity when the body mass index (BMI) presents greater than or equal to 25 and 30 respectively [10]. Obesity is commonly associated with T2D $[11,12]$. In addition, it is a global health problem with a high prevalence among Aborigines [4]. Indigenous presenting DM or not, tend to have a higher pre-valence of overweight/obesity than non-Indigenous. Wang, Hoy \& Si [13] demonstrated that obesity is a relevant factor to increase the DM rates among aborigines. Furthermore, DM has a higher incidence in obese than in non-obese Australians (Table 1) [4]. In addition, Williams et al., [14] showed that BMI values were higher in Aboriginal subjects than in non-Aboriginal, and highest values were found in those with no detectable 


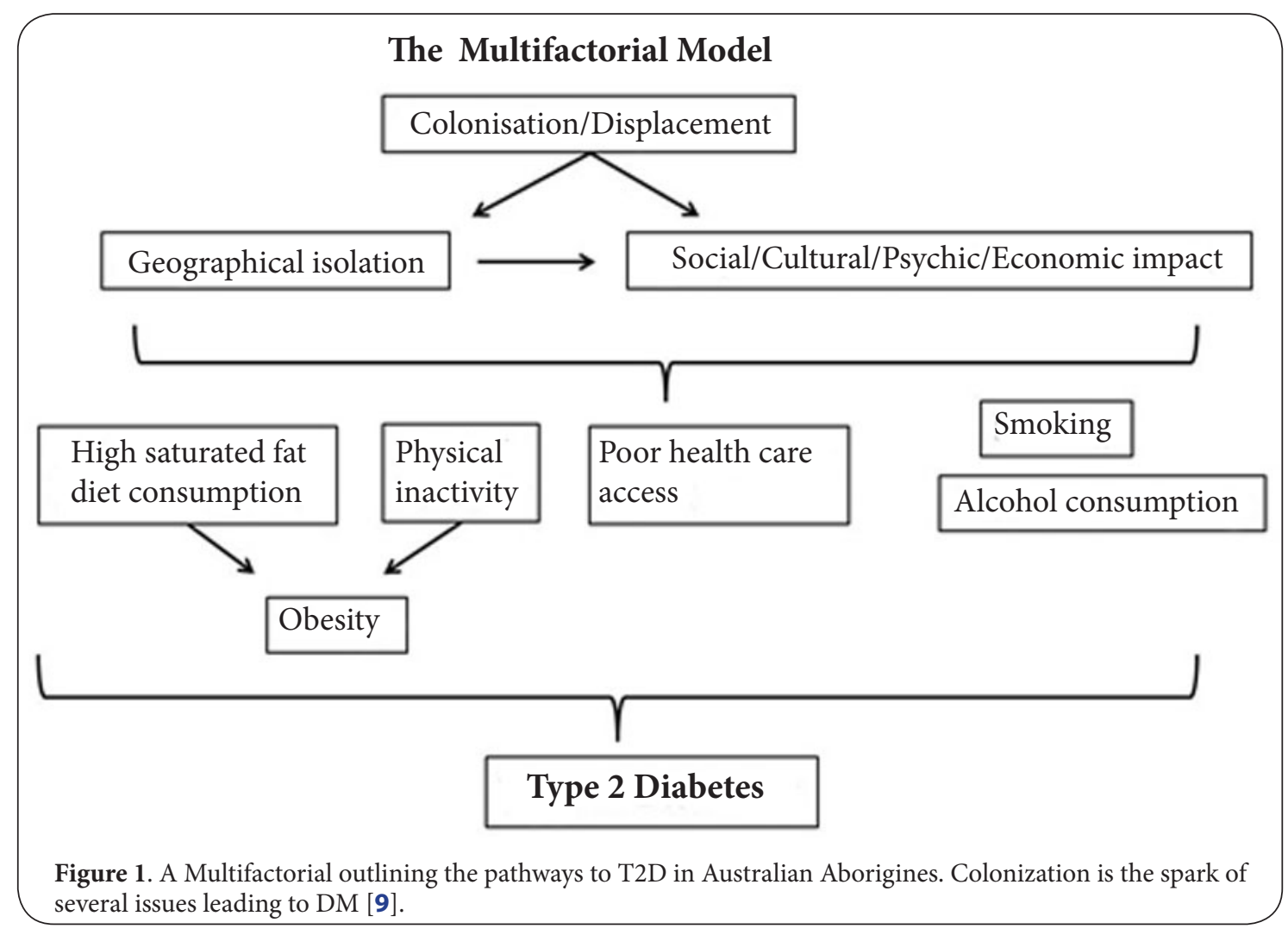

Table 1. Relationship between Obesity and Diabetes Mellitus in Indigenous and non-Indigenous aged 18 years and over, 2004-2005 [4].

\begin{tabular}{l|ll}
\hline \multirow{2}{*}{ Overweight/Obese } & \multicolumn{2}{|c}{ Diabetes Mellitus } \\
\cline { 2 - 3 } & Indigenous & Non-Indigenous \\
\hline Yes (\%) & $17.7^{*}$ & $5.9^{*}$ \\
No (\%) & $8.7^{*}$ & $2.9^{*}$ \\
\hline
\end{tabular}

* Statistically significant difference between Indigenous and non-Indigenous rate.

Caucasian genes. Thus, non-Aboriginal genes may be considered a protective genetic material for DM. Besides the obesity problem, Neel [15] suggested the 'thrifty' genotype hypothesis as a genetic adaptation based on the presumption that the hunter-gatherer experienced alternating periods of feast-or-famine alimentation (Figure 2). However, the previously beneficial gene became deleterious after the alteration of the traditional lifestyle to the westernized one. As a result, the thrifty genotype increases $\mathrm{BMI}$, abdominal fat accumulation and insulin resistance. Together all these facts could lead to the development of DM [16]. In addition, a genome-wide scan conducted in indigenous Australian descent from North Stradbroke Island, Queensland, showed that this community had a positive linkage with T2D on chromosome 2q [17].

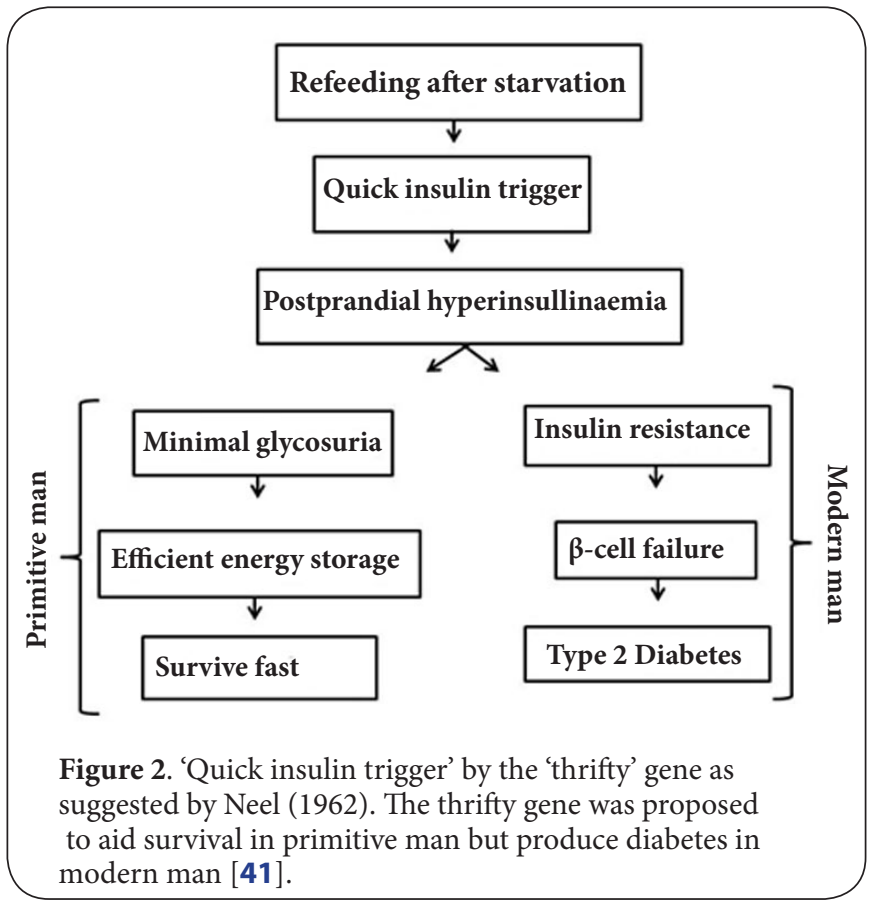

One of the candidate genes of this region is the gene encoding the growth receptor-bound protein (Grb) 14 which has been shown to be a negative regulators of insulin signaling [18]. 
However, the 'thrifty' gene hypothesis is controversial to some experts who maintain that it is a flawed [19] and speculative theory [20]. Speakman [21] reviewed the pros and cons of this debatable theory (Table 2).

Table 2. Pros and cons of the "Thrifty Gene Hypothesis".

\begin{tabular}{ll}
\hline Pros & Cons \\
\hline $\begin{array}{l}\text { Human history of famine } \\
\text { Cannibalism }\end{array}$ & Imprecise/vague estimates of mortality. \\
& -- \\
$\begin{array}{l}\text { Hunter-gathering communities were } \\
\text { less susceptible to famine than after the } \\
\text { agriculture development. }\end{array}$ \\
$\begin{array}{l}\text { Gene mutation (thrifty gene) } \\
\text { creating a survival advantage } \\
\text { (fat storage) }\end{array}$ & $\begin{array}{l}\text { Infectious diseases, rather than } \\
\text { starvation, are the main cause of } \\
\text { Theorticality, an obese person }\end{array}$ \\
$\begin{array}{l}\text { lives longer in condition of } \\
\text { complete absence of food } \\
\text { compared to a lean person }\end{array}$ & $\begin{array}{l}\text { Low prevalence of obesity between } \\
\text { famines. }\end{array}$ \\
\hline
\end{tabular}

\section{Geographical position: urbanization and isolation}

According to the Australian Bureau of Statistics (ABS), in 2011 about $35 \%$ of the Indigenous were living in 'major cities', $44 \%$ in 'regional Australia' and 22\% in isolated areas [22]. Importantly, the geographical isolation is related to a low access to healthcare with late diagnosis and poor understanding of the disease. Isolation reduces the possibility of purchasing fresh fruit and vegetables, influencing negatively in the quality of the diet [23]. However, the BMI and DM rates have been increasing among Aborigines living in remote $[13,23,24]$ and urban areas [25]. In addition, Aboriginal living in remote areas reported almost double the incidence of DM than those living in nonremote areas [4]. However, it has been shown that metabolic syndrome (MetS) prevalence could present regional differences in Aboriginal population [26].

On the other hand, the migration of Aborigines to the cities and consequently the exchanging of the traditional 'hunter-gatherer' lifestyle to the westernized one is a factor that contributes to a caloric diet ingestion and reduction in physical activities which are related to obesity that finally triggers to DM and other MetS [27]. Furthermore, Aborigines in sedentary or moderated practice of physical exercise presented a higher incidence of DM compared to non-Aborigines [4].

Overweight Aborigines after a temporary reversion to a traditional hunter-gatherer lifestyle showed a decreased in fasting glucose, plasma insulin level and plasma triglycerides concentration [28]. In addition, it has been demonstrated that westernization is associated with elevated fasting cholesterol and glucose concentrations in urban Aborigines and Caucasoids compared to rural Aborigines [29]. Conversely, urbanization may be considered a protective factor of DM among Indigenous because of the non-Indigenous admixture [30] as mentioned before.

\section{Smoking}

Smoking has been associated to DM and its complications such as neuropathy, nephropathy, retinopathy, erectile dysfunction and hypertension and the prevention of tobacco is a significant risk factor to control the disease [31]. The incidence of smoking among Aborigines is higher than in non-Aborigines. In 2008, 47\% of Indigenous aged over 15 years used tobacco, but in 2002 the rate was higher, reaching $51 \%$. Although Australian Aborigines present higher prevalence and increased rate of DM and smoking habit compared to non-Aborigines [4,32], smoking has not yet been shown to be a predictor for DM in Australian Aboriginal population [33]. However, smoking is related to other diseases among Aborigines, such as cardiovascular disease [34]. In addition, the high prevalence of smoking in urban Indigenous is similar to remote Aboriginal communities [35].

\section{Conclusion}

Diabetes Mellitus is a chronic and complex disease which involves several factors. However, none in isolation are sufficient to explain the high incidence of DM among Aborigines.

It is concluded that there are three important causes for this problem. Firstly, obesity and the "Thrifty Gene Hypothesis" are related to the alteration of the traditional huntergatherer lifestyle to the westernized one. Secondly, the geographical position determines some aspects that contribute to DM, such as physical activity, the quality of the diet and access to healthcare. And finally, smoking is a behavior that impairs silently many systems, such as circulatory, ocular and renal and increases the risk of DM. Therefore, the following recommendations are proposed to Australian Health Professionals.

\section{Recommendations}

\section{Improvement of genetic research}

As mentioned in Findings and Discussion section, obesity is increasing among Indigenous in Australia. Although the 'Thrifty' gene hypothesis could explain the increase of $\mathrm{BMI}$, it remains controversial. Until now, some studies have confirmed some genes related to DM [36] and obesity [37], but the resolution of this enigma is far from being resolved. Therefore, it is necessary that funds from the government and private initiative be created in order to improve the biogenetic research at Universities.

Improvement of healthcare of indigenous australians in remote areas improvement of medical facilities As described in Findings and Discussion section, low income and isolated geographical position of Indigenous Australians impacts seriously on health. According to the Australian Health Ministers Advisory Council, Indigenous health care 
De Abreu et al. Journal of Medical Disorders 2013,

access issues were higher in remote areas than non-remote areas. In addition, Indigenous Australians are more like to be hospitalized for preventable conditions than non-Indigenous [4]. The Australian Government has a National Rural and Remote Health Infrastructure Program (NRRHIP) which effort is directed to establish new health facilities or improve the existing ones in order to ameliorate the health quality of rural and remote communities (Rural and Regional Health Australia 2012).

Increased employment of indigenous health professionals An additional issue is that Aborigines are often unwilling to use western health care that results in lower treatment access because of western medicine could be culturally unsuitable. Despite the necessity of new Health Centres in remote areas to improve Indigenous health, there is also urgency for an increase in Indigenous workforce in order to provide cultural appropriate health care services [38]. Hence, the Council of Australian Government's (COAG) has incorporated plans of action in order to promote a skilled Indigenous workforce that will provide a better healthcare to communities [39]. This in turn, will provide more health professional positions and thus, improve the standard of living in the community.

\section{Improvement of anti-smoking policies}

It is known that tobacco smoking impairs the health and it is connected to many chronic diseases, such as DM [31]. The Australian Government has implemented a national network of regional tobacco coordinators and tobacco action workers in order to reduce the incidence of smokers in Indigenous communities [40]. The anti-tobacco strategies include prevention and cessation support activities. However, these policies need to be ongoing as a little progress has been made to day and the Australian Indigenous population still remains with a high proportion of heavy smokers compared to the rest of the Australian population.

\section{Competing interests}

The authors declare that they have no competing interests.

\section{Authors' contributions}

\begin{tabular}{|l|c|c|c|}
\hline Authors' contributions & LLFD & KW & YG \\
\hline Research concept and design & $\checkmark$ & -- & $\checkmark$ \\
\hline Collection and/or assembly of data & $\checkmark$ & -- & -- \\
\hline Data analysis and interpretation & $\checkmark$ & -- & -- \\
\hline Writing the article & $\checkmark$ & -- & $\checkmark$ \\
\hline Critical revision of the article & -- & $\checkmark$ & -- \\
\hline Final approval of article & -- & -- & $\checkmark$ \\
\hline Statistical analysis & $\checkmark$ & $\checkmark$ & -- \\
\hline
\end{tabular}

Acknowledgement

LLF de $A$ is supported by a Deakin University Postgraduate Research Scholarship. YG is supported by a Central Research Grant and receive funding from the Molecular \& Medical Research
Strategic Research Centre at Deakin University. Special thank to the Deakin's English Language Institute (DUELI) team.

\section{Publication history}

Senior Editor: Wei Xin, Capital Medical University, China.

Editor: Kentaro Watanabe, Yamagata University Faculty of Medicine, Japan.

Received: 21-Oct-2013 Revised: 29-Nov-2013

Accepted: 05-Dec-2013 Published: 13-Dec-2013

\section{References}

1. World Health Organization. Diabetes Programme. 2013. I Website

2. Zhao Y, Connors C, Wright J, Guthridge S and Bailie R. Estimating chronic disease prevalence among the remote Aboriginal population of the Northern Territory using multiple data sources. Aust N Z J Public Health. 2008; 32:307-13. | Article | PubMed

3. Australian Institute of Health and Wefare. Expenditure on health for Aboriginal and Torres Strait Islander people. An analysis by remoteness and disease. 2008-09. I Pdf

4. Australian Health Ministers Advisory Council. Aboriginal and Torres Strait Islander health performance framework. 2010. | $\underline{\mathrm{Pdf}}$

5. Baier LJ and Hanson RL. Genetic studies of the etiology of type 2 diabetes in Pima Indians: hunting for pieces to a complicated puzzle. Diabetes. 2004; 53:1181-6. | Article | PubMed

6. Zimmet P, Dowse G, Finch C, Serjeantson S and King H. The epidemiology and natural history of NIDDM--lessons from the South Pacific. Diabetes Metab Rev. 1990; 6:91-124. | Article | PubMed

7. Haffner SM, Stern MP, Hazuda HP, Pugh JA and Patterson JK. Hyperinsulinemia in a population at high risk for non-insulin-dependent diabetes mellitus. N Engl J Med. 1986; 315:220-4. I Article I PubMed

8. O'Dea K. Diabetes in Australian aborigines: impact of the western diet and life style. J Intern Med. 1992; 232:103-17. | Article I PubMed

9. Shukla A. Type 2 Diabetes in Indigenous Communities: A Multifactorial Approach. Cross-Sections. 2010; 6:59-71. I Pdf

10. World Health Organisation. Obesity and overweight. 2012. I Website

11. Clinical Guidelines on the Identification, Evaluation, and Treatment of Overweight and Obesity in Adults--The Evidence Report. National Institutes of Health. Obes Res. 1998; 6 Suppl 2:51S-209S. | PubMed

12. Zimmet PZ. Diabetes epidemiology as a tool to trigger diabetes research and care. Diabetologia. 1999; 42:499-518. | Article | PubMed

13. Wang Z, Hoy WE and Si D. Incidence of type 2 diabetes in Aboriginal Australians: an 11-year prospective cohort study. BMC Public Health. 2010; 10:487. | Article | PubMed Abstract | PubMed Full Text

14. Williams DR, Moffitt PS, Fisher JS and Bashir HV. Diabetes and glucose tolerance in New South Wales coastal Aborigines: possible effects of non-Aboriginal genetic admixture. Diabetologia. 1987; 30:72-7. | PubMed

15. Neel JV. Diabetes mellitus: a "thrifty" genotype rendered detrimental by "progress"?. Am J Hum Genet. 1962; 14:353-62. I Pdf I PubMed Abstract | PubMed Full Text

16. Khamaisi M and Raz I. Diabetes epidemic and the thrifty gene. Isr Med Assoc J. 2002; 4:720-1. | Article | PubMed

17. Busfield F, Duffy DL, Kesting JB, Walker SM, Lovelock PK, Good D, Tate H Watego D, Marczak M, Hayman N and Shaw JT. A genomewide search for type $\mathbf{2}$ diabetes-susceptibility genes in indigenous Australians. Am J Hum Genet. 2002; 70:349-57. I Article | PubMed Abstract | PubMed Full Text

18. Kasus-Jacobi A, Perdereau D, Auzan C, Clauser E, Van Obberghen E, Mauvais-Jarvis F, Girard J and Burnol AF. Identification of the rat adapter Grb14 as an inhibitor of insulin actions. J Biol Chem. 1998; 273:2602635. | Article I PubMed

19. Speakman JR. Thrifty genes for obesity, an attractive but flawed idea, 
and an alternative perspective: the 'drifty gene' hypothesis. Int $\mathrm{J}$ Obes (Lond). 2008; 32:1611-7. | Article | PubMed

20. Prentice AM, Hennig BJ and Fulford AJ. Evolutionary origins of the obesity epidemic: natural selection of thrifty genes or genetic drift following predation release? Int J Obes (Lond). 2008; 32:1607-10. | Article | PubMed

21. Speakman JR. Thrifty genes for obesity and the metabolic syndrome-time to call off the search? Diab Vasc Dis Res. 2006; 3:7-11. | Article | PubMed

22. Australian Bureau of Statistics. Estimates of Aboriginal and Torres Strait Islander Australians. 2011. | Website

23. O'Dea K, Patel M, Kubisch D, Hopper J and Traianedes K. Obesity, diabetes, and hyperlipidemia in a central Australian aboriginal community with a long history of acculturation. Diabetes Care. 1993; 16:1004-10. | Article | PubMed

24. McDermott R, Rowley KG, Lee AJ, Knight S and O'Dea K. Increase in prevalence of obesity and diabetes and decrease in plasma cholesterol in a central Australian aboriginal community. Med J Aust. 2000; 172:480-4. | Article | PubMed

25. O'Dea K, Cunningham J, Maple-Brown L, Weeramanthri T, Shaw J, Dunbar $T$ and Zimmet $P$. Diabetes and cardiovascular risk factors in urban Indigenous adults: Results from the DRUID study. Diabetes Res Clin Pract. 2008; 80:483-9. | Article | PubMed

26. Luke JN, Brown A, Daniel M, O'Dea K, Best JD, Jenkins AJ, Wang Z, McDermott RA and Rowley KG. The metabolic syndrome and CVD outcomes for a central Australian cohort. Diabetes Res Clin Pract. 2013; 100:e70-3. | Article | PubMed

27. O'Dea K. Westernisation, insulin resistance and diabetes in Australian aborigines. Med J Aust. 1991; 155:258-64. | Article | PubMed

28. O'Dea K. Marked improvement in carbohydrate and lipid metabolism in diabetic Australian aborigines after temporary reversion to traditional lifestyle. Diabetes. 1984; 33:596-603. | Article | PubMed

29. O'Dea K, Spargo RM and Nestel PJ. Impact of Westernization on carbohydrate and lipid metabolism in Australian Aborigines. Diabetologia. 1982; 22:148-53. | Article | PubMed

30. Minges KE, Zimmet P, Magliano DJ, Dunstan DW, Brown A and Shaw $\mathrm{JE}$. Diabetes prevalence and determinants in Indigenous Australian populations: A systematic review. Diabetes Res Clin Pract. 2011; 93:13949. | Article | PubMed

31. Haire-Joshu D, Glasgow RE and Tibbs TL. Smoking and diabetes. Diabetes Care. 1999; 22:1887-98. | Article | PubMed

32. Marley JV, Nelson C, O'Donnell V and Atkinson D. Quality indicators of diabetes care: an example of remote-area Aboriginal primary health care over 10 years. Med J Aust. 2012; 197:404-8. | Article | PubMed

33. McDermott RA, McCulloch BG, Campbell SK and Young DM. Diabetes in the Torres Strait Islands of Australia: better clinical systems but significant increase in weight and other risk conditions among adults, 1999-2005. Med J Aust. 2007; 186:505-8. | Article | PubMed

34. Gault A, O'Dea K, Rowley KG, McLeay T and Traianedes K. Abnormal glucose tolerance and other coronary heart disease risk factors in an isolated aboriginal community in central Australia. Diabetes Care. 1996; 19:1269-73. | Article | PubMed

35. Davis TM, Hunt K, McAullay D, Chubb SA, Sillars BA, Bruce DG and Davis WA. Continuing disparities in cardiovascular risk factors and complications between aboriginal and Anglo-Celt Australians with type 2 diabetes: the Fremantle Diabetes Study. Diabetes Care. 2012; 35:2005-11. | Article | PubMed Abstract | PubMed Full Text

36. Frayling TM. Genome-wide association studies provide new insights into type 2 diabetes aetiology. Nat Rev Genet. 2007; 8:657-62. | Article | PubMed

37. Frayling TM, Timpson NJ, Weedon MN, Zeggini E and Freathy RM. A common variant in the FTO gene is associated with body mass index and predisposes to childhood and adult obesity. Science. 2007; 316:88994. | Article | PubMed Abstract | PubMed Full Text

38. Turale $S$ and Miller M. Improving the health of Indigenous Australians: reforms in nursing education. An opinion piece of international interest.
Int Nurs Rev. 2006; 53:171-7. | Article | PubMed

39. Commonwealth of Australia. Remote Service Delivery National Partnership Agreement Annual Report to COAG. 2010; 1-17. | Article

40. Australian Government. Closing the Gap: The Indigenous Chronic Disease Package. 2010. | Pdf

41. Reaven GM. Hypothesis: muscle insulin resistance is the ("not-so") thrifty genotype. Diabetologia. 1998; 41:482-4. | Article | PubMed

\section{Citation:}

de Abreu LLF, Walder K and Gibert Y. Diabetes mellitus in the australian indigenous community. J Med Disord. 2013; 1:4. http://dx.doi.org/10.7243/2053-3659-1-4 